\title{
Thermodynamic comparison of the FICFB and Viking gasification concepts
}

\author{
Martin Gassner, François Maréchal \\ Laboratory for Industrial Energy Systems \\ Ecole Polytechnique Fédérale de Lausanne \\ $\mathrm{CH}$ - 1015 Lausanne, Switzerland \\ Energy (2009), in press, doi:10.1016/j.energy.2009.05.011
}

\begin{abstract}
Two biomass gasification concepts, i.e. indirectly heated, fast internally circulating fluidised bed (FICFB) gasification with steam as gasifying agent and two-stage, directly heated, fixed bed Viking gasification are compared with respect to their performance as gas generators. Based on adjusted equilibrium equations, the gas composition and the energy requirements for gasification are accurately modelled. Overall energy balances are assessed by an energy integration with the heat cascade concept and considering energy recovery in a steam Rankine cycle. A detailed inventory of energy and exergy losses of the different process sections is presented and potential process improvements due to a better utility choice or feed pretreatment like drying or pyrolysis are discussed. While Viking gasification performs better as an isolated gas generator than state-of-the-art FICFB gasification, there is large potential for improvement of the FICFB system. Furthermore, a concluding analysis of the gasification systems in an integrated plant for synthetic natural gas production shows that FICFB gasification is more suitable overall due to a more advantageous energy conversion related to the producer gas composition.
\end{abstract}

Keywords: gasification, modelling, energy integration, exergy analysis, SNG

\section{Nomenclature}

\begin{tabular}{|c|c|}
\hline \\
\hline \multicolumn{2}{|c|}{ FICFB Fast internally circulating fluidised bed } \\
\hline HHV & Higher heating value \\
\hline ITM & Ion transfer membrane \\
\hline LHV & Lower heating value \\
\hline MER & Minimum energy requirement \\
\hline SNG & Synthetic natural gas \\
\hline \multicolumn{2}{|c|}{ Roman letters } \\
\hline$c_{p}$ & Specific heat at constant pressure \\
\hline$\dot{E}$ & Mechanical or electrical power \\
\hline$\dot{E}_{q}$ & Heat exergy \\
\hline$\dot{E}_{y}$ & Exergy of material streams \\
\hline$k_{p}$ & Partial pressure ratio between $\mathrm{C}_{2} \mathrm{H}_{4}$ and $\mathrm{CH}_{4}$ \\
\hline$K_{p}$ & Equilibrium constant based on pressure \\
\hline$\hat{K}_{p}$ & Apparent equilibrium constant \\
\hline$\dot{L}$ & Exergy loss \\
\hline$\dot{m}$ & Mass flow \\
\hline$p$ & Pressure \\
\hline
\end{tabular}


$\dot{Q} \quad$ Heat $\quad \mathrm{kW}$

$T$ Temperature $\quad{ }^{\circ} \mathrm{C}$

$\begin{array}{lll}T_{a} & \text { Atmospheric temperature } & { }^{\circ} \mathrm{C}\end{array}$

$T_{g} \quad$ Gasification temperature $\quad{ }^{\circ} \mathrm{C}$

$T_{a, d} \quad$ Air temperature at dryer inlet $\quad{ }^{\circ} \mathrm{C}$

Greek letters

$\begin{array}{lll}\Delta \tilde{h}_{r}^{0} & \text { Standard heat of reaction } & \mathrm{kJ} / \mathrm{mol}\end{array}$

$\Delta h_{\text {vap }} \quad$ Latent heat of vaporisation $\quad \mathrm{kJ} / \mathrm{kg}$

$\Delta h_{i}^{0} \quad$ Lower heating value of substance i $\quad \mathrm{kJ} / \mathrm{kg}$

$\begin{array}{lll}\Delta k_{i}^{0} & \text { Exergy value of substance i } & \mathrm{kJ} / \mathrm{kg}\end{array}$

$\Delta p \quad$ Pressure drop bar

$\Delta T \quad$ Temperature difference $\quad{ }^{\circ} \mathrm{C}$

$\varepsilon \quad$ Energy efficiency $\%$

$\eta \quad$ Exergy efficiency $\%$

$\Phi_{\text {wood }}$ Wood humidity $\%$ wt

Subscripts

$b d \quad$ Boudouard equilibrium

cg Cold gas

el Electric

$h$ Hydrogenating gasification equilibrium

HT Heat transfer

th Thermal

tot Total

$w g \quad$ Water gas shift equilibrium

\section{Superscripts}

$0 \quad$ Standard conditions

$+\quad$ Material or energy stream entering the system

- $\quad$ Material or energy stream leaving the system

\section{Introduction}

Due to its renewable character, biomass and waste gasification is commonly considered as one of the promising technologies for rational and carbon-neutral conversion of energy (Perry et al., 2008). Besides the traditional application of this technology for generating power in centralised combined cycle plants (Craig and Mann, 1996; Brown et al., 2009) or in the local production of combined heat and power using gas engines (Hofbauer et al., 2002; Henriksen et al., 2006; Yoshikawa, 2006) and more recently fuel cells (Omosun et al., 2004; Karellas et al., 2008), there is currently also a large interest in processes for the synthesis of liquid and gaseous fuels (Spath and Dayton, 2003; Mozaffarian and Zwart, 2003; Hamelinck et al., 2004; Duret et al., 2005; Gassner and Maréchal, 2009b; Heyne et al., 2008; Ptasinski, 2008; Luterbacher et al., 2009).

In process design, suitable biomass gasification technology is usually identified considering design constraints like capacity and criteria like gas composition, calorific value and contaminants that are related to the specific application (Mozaffarian and Zwart, 2003; Hamelinck et al., 2004; Stucki, 2005). Process integration aspects are regarded to a lesser extent, although heat requirements of gasifiers are generally important and influence the systems' overall performance markedly. Especially for biomassbased fuel production, a high chemical gas conversion is essential since the primary product is the energy stored in the material outlet streams. Furthermore, the energy requirements and recovery possibilities of the reforming steps after gasification are different to those in power generation, and proven technology established for this specific application does not necessarily fit the modified demand.

For this reason, the present paper investigates the thermodynamic performance of two potential gasification systems for fuel production as producer gas generators. Several authors have recently investigated 
the thermodynamic and exergetic performance of gasification (Ptasinski et al., 2007; Jarungthammachote and Dutta, 2007; Prins et al., 2007) and gasification systems for the production of power (Brown et al., 2009; Prins et al., 2007; Fryda et al., 2008) and fuels (Ptasinski, 2008). Apart from (Brown et al., 2009), however, all these studies disregard or discuss the effects of process integration only very briefly, and lack a systematic approach as provided by pinch analysis techniques. The present work paper therefore focusses on the integrated energetic and exergetic performance and addresses two exemplary gasification systems for whom this type of analysis has yet to be carried out. In particular, an indirectly heated fluidised bed gasifier with steam as gasifying agent (FICFB process (Hofbauer et al., 2002)) - being currently regarded as promising option for synthetic natural gas (SNG) production (Heyne et al., 2008; Stucki, 2005) - and a directly heated, fixed bed gasifier based on a relatively novel two-stage concept (Viking process (Henriksen et al., 2006)) are compared.

In the first step of the analysis, process models based on adjusted equilibrium equations are developed to investigate the level of thermodynamic conversion of the produced gas. The heat requirements of the gasification process are then used in an energy integration to determine the overall thermodynamic performance of the system. By assessing the energy and exergy losses in the different process sections in detail, both systems are compared and potential improvements are proposed. Finally, the performances of an integrated SNG plant are assessed for both gasification systems and confronted with their isolated performance as gas generators.

\section{Process description}

Developed at the Technical University of Vienna, FICFB gasification has been designed as an internally circulating fluidised bed system where heat is transferred by circulating the bed material between two physically separated gasification and combustion chambers (Hofbauer et al., 2002). As shown on the left of Figure 1, gasifying steam is injected into a stationary fluidised bed where drying, pyrolysis and gasification of the raw material take place. The reactor is heated indirectly by transferring hot bed material via a cyclone from a combustion chamber, where the ungasified char and additional fuel typically cold producer gas - are oxidised. The obtained synthesis gas is cooled to $150 \mathrm{C}$, filtered and washed with water or biodiesel in order to remove dust particles, tar and other contaminants before being used in an energy conversion unit or a fuel conversion process.

The fundamental design idea behind the Viking gasification process developed at the Technical University of Denmark is to perform a thermally staged gasification with intermediate partial oxidation for tar cracking (Henriksen et al., 2006). As shown on the conceptual flowsheet (Fig. 1, right), wood is first conveyed through a screw pyrolysis unit, where it is heated to $500-600^{\circ} \mathrm{C}$ and partially decomposed. After thermal cracking of the tars through partial oxidation of the gas phase, the remaining solid species are gasified in a fixed bed. The synthesis gas leaving the gasifier at $700-800^{\circ} \mathrm{C}$ is cooled to $90^{\circ} \mathrm{C}$ and filtered. Finally, the condensates are removed at ambient conditions in a gas-liquid separator.

\section{Process modelling}

\subsection{Method}

Following a systematic methodology for preliminary process design and analysis (Gassner and Maréchal, 2009a), the thermodynamic process modelling is performed in two successive steps. First, commercial flowsheeting software (Belsim SA, last visited 04/2009) is used to calculate the operation of the process units by applying conservation principles and simple model equations. From this energy-flow model, the heat and power requirements are identified and transferred to the energy-integration model. In this second step, the combined production of gas and power from residual heat below the pinch is maximised. Since the operating conditions of the non-linear energy-flow model are fixed after the first step, the energyintegration model can be formulated as a linear subproblem, which is resolved by mixed integer linear programming minimising the operating cost and considering the heat cascade equations as constraints 


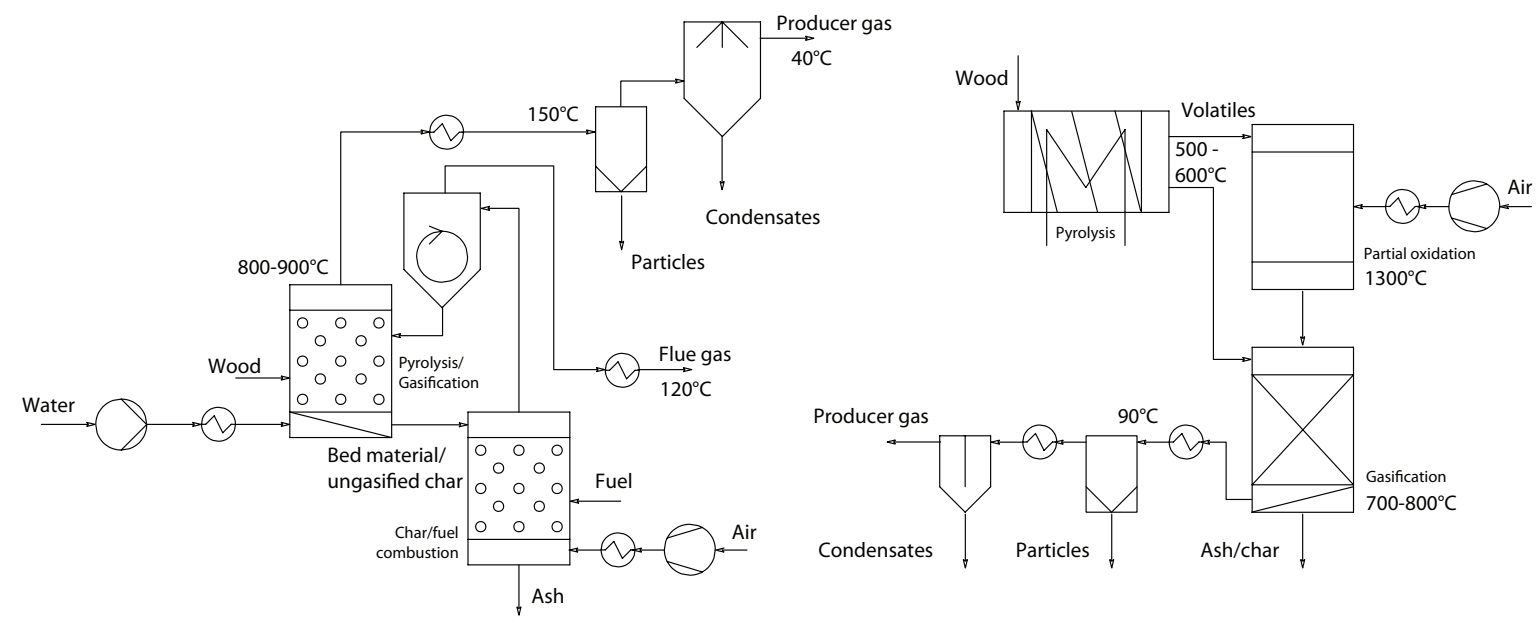

Figure 1: Conceptual flowsheets for FICFB (left) and Viking gasification (Note: The purpose of these schematics is to illustrate the model structure and does not correspond to the physical process layout, i.e. the pyrolysis, oxidation/combustion and gasification reactors correspond to one physical unit.)

(Gassner and Maréchal, 2009a). One of the key advantages of this approach is that the topology of the heat exchanger network and the fuel supply for indirectly heated gasification are not defined a priori, but computed in the integration step, which makes the method very suitable for preliminary process design. In addition, as the heat transfer and the chemical conversion are addressed separately, this approach allows for better understanding the exergy losses in the heat transfer operations with a systematic vision since it considers all the possible heat recovery by heat exchange.

\subsection{Energy-flow models}

\subsubsection{Gasification}

Due to the inherent need for simple model equations in flowsheet calculations, gasification systems are often modelled assuming thermodynamic equilibrium of the gas phase at the reactor outlet, as for example for steam gasification in (Schuster et al., 2001). However, comparisons with experimental data show that this is generally not a valid assumption and kinetic effects must be taken into account. Many authors, for example (Li et al., 2004; Pellegrini and de Oliveira Jr., 2007; Pröll and Hofbauer, 2008), therefore fix the carbon conversion and/or the fraction of methane and higher hydrocarbons, or correct the equilibrium constant with a multiplication factor (Jarungthammachote and Dutta, 2007; Huang and Ramaswamy, 2009). Introduced by Gumz (1950) and discussed for the application to biomass gasification by for instance (Prins et al., 2007) and in more detail by (Bacon et al., 1982; Kersten, 2002; Brown, 2007), a thermodynamically more consistent way to adjust the equilibrium equations is to correct the equilibrium temperature by introducing artificial temperature differences $\Delta T$ of the form:

$$
\hat{K}_{p}=K_{p}\left(T_{g}+\Delta T\right)
$$

where $K_{p}$ is the theoretical equilibrium constant and $\hat{K}_{p}$ the apparent equilibrium constant corresponding to the experimentally observed composition at the gasification temperature $T_{g}$. By adjusting the $\Delta T$ with experimental data, it is possible to use a simple thermodynamic relationship to correctly compute both the gas compositions and energy balance around the nominal operation conditions and to model the influence of the design variables of the gasifier.

Considering that the outlet streams of the gasifiers consist of $\mathrm{H}_{2}, \mathrm{CO}, \mathrm{CO}_{2}, \mathrm{CH}_{4}, \mathrm{H}_{2} \mathrm{O}, \mathrm{N}_{2}$ and $\mathrm{C}(\mathrm{s})$, three equations in addition to the atomic balances are required to determine the gas composition. In our model, two solid-gas, i.e. the hydrogenating gasification (Eq. 2) and the Boudouard (Eq. 3) equilibria, 
and the water-gas shift (Eq. 4) reactions have been used:

$$
\begin{array}{ll}
\mathrm{C}(\mathrm{s})+2 \mathrm{H}_{2} \rightleftharpoons \mathrm{CH}_{4} & \Delta \tilde{h}_{r}^{0}=-75 \mathrm{~kJ} / \mathrm{mol} \\
\mathrm{C}(\mathrm{s})+\mathrm{CO}_{2} \rightleftharpoons 2 \mathrm{CO} & \Delta \tilde{h}_{r}^{0}=+173 \mathrm{~kJ} / \mathrm{mol} \\
\mathrm{CO}+\mathrm{H}_{2} \mathrm{O} \rightleftharpoons \mathrm{CO}_{2}+\mathrm{H}_{2} & \Delta \tilde{h}_{r}^{0}=-41 \mathrm{~kJ} / \mathrm{mol}
\end{array}
$$

In FICFB gasification, experimental data of the gasifier shows that higher hydrocarbons are produced, which could as well be represented by an adjusted equilibrium equation in the form of Eq. 1. However, very high values are typically found and indicate that the mathematical representation has no physical meaning. Its amount is therefore calculated assuming that they are appropriately represented by ethene and that its partial pressure is proportional to one of methane:

$$
p_{C 2 H 4}=k_{p} p_{C H 4}
$$

According to these equations, the four parameters to be fitted in the gasification models are $\Delta T_{h g}$ (Eq. 2), $\Delta T_{b d}$ (Eq. 3), $\Delta T_{w g}$ (Eq. 4) and $k_{p}$ (Eq. 5).

\subsubsection{Pyrolysis}

The equilibrium-based models represent the products and heat demand of gasification with reasonable accuracy, but do not allow for taking the bulk formation of condensable hydrocarbons during pyrolysis into account. A recently published experimental study (Fassinou et al., 2009) of the screw pyrolysis section of the Viking systems show that these condensable substances (incl. $\mathrm{H}_{2} \mathrm{O}$ ) contribute to 28$78 \%$ wt of the gaseous phase from pyrolysis. Although some yield data and the detailed non-condensable gas composition are reported, no complete mass- and energy-balances can be deduced from the given information. Model validation is thus impossible, and no rigorous model for the conversion of species in the pyrolysis has been developed. Instead, a simplified formulation based on a partial gasification of the biomass feed is adopted. It is considered that the atomic species in the biomass are uniformly gasified, which fixes the solid composition. Assuming further that the complete volatile fraction identified in the proximate analysis is released, two model equations are necessary to fix the gas phase composition and the heat demand. For this purpose, the hydrogenating gasification (Eq. 2) and water-gas shift (Eq. 4) reactions are used and reconciled with the consistent dataset for the overall plant.

\subsubsection{Data reconciliation}

With the general assumptions and operating conditions detailed in Tables 1 and 2, the model parameters of the gasification reactor model are determined using data of wood characteristics, process conditions and gas compositions from Gøbel et al. (2004); Henriksen et al. (2005); Rauch (written around 2004). For FICFB gasification, the reference temperature for gasification is $850^{\circ} \mathrm{C}$, while the artificial temperature differences in Viking gasification refer to pyrolysis and gasification temperatures of $600 \mathrm{C}$ and $750^{\circ} \mathrm{C}$ respectively. The values of the identified parameters and their accuracy with respect to the measured data are given in Tables 3 and 4.

\subsubsection{Error analysis}

According to Table 4, the model is able to accurately reproduce the measured composition of the producer gas. Except for the $\mathrm{CO}_{2}$ fraction of the FICFB reactor with a relative error of 5.5\%, all calculated compositions are within a 5\% error range. As already discussed in Section 3.2.2, the model parameters and gas composition after pyrolysis must however be considered as artificial since the higher hydrocarbons are not explicitly included as model species, but partially accounted for by the non-condensable species and the ungasified raw material. According to experimental data, about $14 \%$ vol $\mathrm{CH}_{4}, 40 \%$ vol $\mathrm{CO}, 18 \%$ vol $\mathrm{CO}_{2}, 19 \%$ vol $\mathrm{H}_{2}$ and $3 \%$ vol $\mathrm{C}_{4} \mathrm{H}_{4-6}$ are typically obtained in the dry, non-condensable product at nominal conditions (Fassinou et al., 2009). However, for the validity of the following energy 


\begin{tabular}{lccc}
\hline Parameter & Unit & FICFB & Viking \\
\hline$\varepsilon_{\text {isentropic,turbomachinery }}$ & $\%$ & 80 & 80 \\
$\Delta p_{\text {exchangers }}$ & bar & - & - \\
$\Delta p_{\text {filter }}$ & bar & 0.10 & 0.10 \\
$\Delta p_{\text {gasifier }}$ & bar & 0.15 & 0.05 \\
Carbon conversion & $\%$ & 90 & 99 \\
Gasifier heat loss & $\%$ & $10^{\mathrm{a}}$ & $2^{\mathrm{b}}$ \\
Volatiles $^{c}$ & $\% \mathrm{wt}$ & - & 84 \\
Wood humidity $\left(\Phi_{\text {wood }}\right)^{\mathrm{c}}$ & $\%$ & 30 \\
\hline
\end{tabular}

a based on transferred heat

$\mathrm{b}$ based on lower heating value of feed

c according to data used for reconciliation (Henriksen et al., 2005; Rauch, written around 2004)

Table 1: Model assumptions.

\begin{tabular}{lccc}
\hline Operating conditions & Unit & FICFB & Viking \\
\hline Steam preheat temperature & ${ }^{\circ} \mathrm{C}$ & 500 & - \\
Air preheat temperature & ${ }^{\circ} \mathrm{C}$ & 600 & 600 \\
Steam/biomass ratio & - & 0.6 & - \\
\hline
\end{tabular}

Table 2: Operating conditions.

\begin{tabular}{lccc}
\hline Process & FICFB & Viking & Gasification \\
Reactor & Gasification & Pyrolysis & $-11^{\circ} \mathrm{C}$ \\
\hline$\Delta T_{h g}$ & $-260^{\circ} \mathrm{C}$ & $-289^{\circ} \mathrm{C}$ & $-123^{\circ} \mathrm{C}$ \\
$\Delta T_{b d}$ & $-201^{\circ} \mathrm{C}$ & - & $-126^{\circ} \mathrm{C}$ \\
$\Delta T_{w g}$ & $-112^{\circ} \mathrm{C}$ & $+12^{\circ} \mathrm{C}$ & 0 \\
$k_{p}$ & 0.204 & 0 & 0 \\
\hline
\end{tabular}

Table 3: Reconciled model parameters.

\begin{tabular}{lcc|ccc}
\hline $\begin{array}{l}\text { Process } \\
\text { Reactor } \\
\text { State }\end{array}$ & wet & gasification & \multicolumn{2}{c}{ pyrolysis } & \multicolumn{2}{c}{ gasification } \\
wet & $-/ 1.9$ & $-/-$ & $-/-$ & wet \\
$\mathrm{C}_{2} \mathrm{H}_{4}$ & $1.8 / 1.8$ & $-/ 9.3$ & $-/ 35.7$ & $-/ 1.2$ & $1.2 / 1.2$ \\
$\mathrm{CH}_{4}$ & $8.8 / 9.0$ & $-/ 41.0$ & $-/ 4.9$ & $-/ 30.4$ & $30.5 / 31.4$ \\
$\mathrm{H}_{2}$ & $37.3 / 39.5$ & $-/ 28.9$ & $-/ 3.0$ & $-/ 18.3$ & $19.6 / 19.0$ \\
$\mathrm{CO}$ & $29.4 / 28.0$ & $-/ 15.9$ & $-/ 33.2$ & $-/ 14.2$ & $15.4 / 14.7$ \\
$\mathrm{CO}_{2}$ & $16.2 / 15.3$ & $-/ 3.0$ & $-/ 0.2$ & $-/ 32.7$ & $33.3 / 33.7$ \\
$\mathrm{~N}_{2}$ & $2.9 / 2.9$ & $-/-$ & $-/ 23.0$ & $-/ 3.2$ & $-/-$ \\
$\mathrm{H}_{2} \mathrm{O}$ & $3.6 / 3.5$ & & &
\end{tabular}

Table 4: Gasifier outlet compositions in \%vol (Data (Gøbel et al., 2004; Rauch, written around 2004) / Calculation). 
integration and exergy analysis, the accuracy of the intermediate composition has no influence since only a correct reproduction of the heat demand for pyrolysis is crucial. Indeed, this is assured by the computed nitrogen fraction in the producer gas, which is in very good agreement with the data from the plant. As it enters the reactor in a known ratio to oxygen, this fraction directly represents the degree of partial oxidation in the gasification. The enthalpy balance of the gasification reactor is thus accurate, which also implies that the total enthalpy of the close-coupled pyrolysis products is correct.

\subsubsection{Discussion}

Examining the reconciled model parameters, it is obvious that the synthesis gas from both gasifiers is not in thermodynamic equilibrium. All the apparent equilibrium temperatures observed in the gasification sections are below the actual reactor temperatures. Compared to equilibrium, the gasifiers produce gases that contain too much hydrocarbons and carbon dioxide and too little hydrogen and carbon monoxide. The difference from equilibrium is thereby not as substantial in case of Viking gasification, which may be due to the different reactor types. A previous study (Gassner and Maréchal, 2009b) observed similar temperature deviations for air blown and steam blown gasifiers of fluidised bed type and reasoned similar catalytic activity of the bed. Unlike in fluidised bed reactors, the temperature in fixed beds is not equally distributed and part of the gas might be formed at higher temperatures. In case of Viking gasification, the pyrolysis gas is furthermore heated to $1100^{\circ} \mathrm{C}$ by partial oxidation in order to thermally crack the tars. Since this shifts the gas equilibrium towards $\mathrm{H}_{2}$ and $\mathrm{CO}$ and reaction kinetics tend to accelerate with temperature, this might also lead to approach thermodynamic equilibrium at the gasifier outlet to a greater extent.

\subsection{Energy integration}

\subsubsection{Problem definition}

After the calculation of the thermodynamic unit conversions in the energy-flow models, the energy integration of the process is performed. For this purpose, the heat requirements of the process streams, available utilities and energy recovery technology are assembled in the heat cascade formulation, which is used to model the heat exchanger network (Gassner and Maréchal, 2009a).

In this analysis, the heat demand above the pinch is satisfied through combustion of cold producer gas and ungasified char. In directly heated gasification, residual char is diluted in the ash and cannot be recovered. Excess heat below the pinch is recovered and converted to electricity by a steam Rankine cycle. In this work, typical small scale operating conditions of 60 bar for steam production and 500C for steam superheating are assumed. Two intermediate steam utilisation levels at 15.5 bar $\left(200^{\circ} \mathrm{C}\right)$ and $1.0 \mathrm{bar}\left(100^{\circ} \mathrm{C}\right)$ and one condensation level at $0.23 \mathrm{bar}\left(20^{\circ} \mathrm{C}\right)$ fed with cooling water are used. Partial condensation in a condensing stage is allowed to minimum vapour fraction of $85 \%$, and isentropic efficiencies for the backpressure and condensing turbine stages are of $80 \%$ and $70 \%$, respectively. In the heat cascade formulation, minimum approach temperatures of $8^{\circ} \mathrm{C}, 4^{\circ} \mathrm{C}$ and $2^{\circ} \mathrm{C}$ for gaseous, liquid and condensing or evaporating streams, respectively, are assumed. For the heat transfer to the reactive sections (pyrolysis, FICFB-gasification) and from the fumes down to a stack temperature of $120 \mathrm{C}$, the minimum approach temperature is set to $25^{\circ} \mathrm{C}$.

The performance of the process is assessed by calculating the energy balances, the cold gas efficiency $\varepsilon_{c g}$ (Eq. 6) and the overall energy efficiency $\varepsilon_{t o t}$ (Eq. 7), defined as:

$$
\begin{aligned}
\varepsilon_{c g} & =\frac{\Delta h_{\text {gas }}^{0} \dot{m}_{\text {gas }}}{\Delta h_{\text {wood }}^{0} \dot{m}_{\text {wood }}} \\
\varepsilon_{\text {tot }} & =\frac{\Delta h_{\text {gas }}^{0} \dot{m}_{\text {gas }}+\dot{E}^{-}}{\Delta h_{\text {wood }}^{0} \dot{m}_{\text {wood }}+\dot{E}^{+}}
\end{aligned}
$$

where $\Delta h^{0}$ and $\dot{m}$ designate the lower heating value per unit mass and the mass flow, respectively. $\dot{E}^{-}$ 


\begin{tabular}{|c|c|c|c|}
\hline \multicolumn{2}{|c|}{ Proximate analysis } & \multicolumn{2}{|c|}{ Ultimate analysis } \\
\hline$\overline{\Delta h_{\text {wood,dry }}^{0}}$ & $19.2 \mathrm{MJ} / \mathrm{kg}_{d r y}$ & $\bar{C}$ & $50.93 \% \mathrm{wt}$ \\
\hline$\Delta h_{\text {wood }}^{0}{ }^{0}$ & $18.2 \mathrm{MJ} / \mathrm{kg}_{d r y}$ & $\mathrm{H}$ & $6.11 \% \mathrm{wt}$ \\
\hline$\Delta k_{\text {wood }}^{0}$ & $21.6 \mathrm{MJ} / \mathrm{kg}_{d r y}$ & $\mathrm{O}$ & $42.16 \% \mathrm{wt}$ \\
\hline$\Phi_{\text {wood }}$ & $30 \% \mathrm{wt}$ & $\mathrm{N}$ & $0.80 \% \mathrm{wt}$ \\
\hline
\end{tabular}

Table 5: Feedstock properties.

refers to overall produced and $\dot{E}^{+}$to overall consumed power, whereas one of these terms is equal to zero since only the overall balance is of interest.

For a proper comparison of the gasification systems, the same feedstock properties as shown in Table 5 and an arbitrary total energy input of $1 \mathrm{MW}_{t h \text {,wood }}$ are chosen since the model is independent of the equipment size.

\subsubsection{Results and Discussion}

The resulting energy balances and composite curves without and with a steam cycle for energy recovery are depicted in Table 6 and Figure 2. The data reveals a considerable difference of the performance of the investigated gasification systems. In case of FICFB gasification, only $78 \%$ of the chemical energy input is converted into product, while $91 \%$ are recovered in Viking gasification. From the energy loss inventory, it is seen that the lower carbon conversion in FICFB gasification is not the reason for the difference since it is used as fuel in the combustion. However, significant amounts of energy are lost in the gas cooling and cooling water, and a considerable by-production of electricity is observed. The composite curves show that the FICFB gasification system is pinched at $875^{\circ} \mathrm{C}$, and of the endothermal reaction must be supplied at this high temperature. From the whole demand of $266 \mathrm{~kW}_{t h} / \mathrm{MW}_{\text {wood }}$, only $30 \%$ are satisfied with the ungasified char and $19 \%$ of the total cold producer gas is required to supply the remaining $70 \%$. Consecutively, an important amount of $148 \mathrm{~kW}_{t h} / \mathrm{MW}_{\text {wood }}$ of sensible heat of the fumes and wet producer gas is available below the pinch, from which $36 \%$ can be recovered as electricity with a Rankine cycle (Fig. 2b). In Viking gasification, the heat demand is satisfied by partial oxidation inside the reactor and the composite curves do not show a process pinch due to heat transfer. The key advantage of this technology in terms of gas efficiency is however caused by the staged gasification concept. In contrast to FICFB gasification where the entire heat demand for the decomposition must be withdrawn from the chemical energy of the material streams, part of this demand is satisfied by recovering the sensible heat from the producer gas in the pyrolysis. Less heat is thereby released from the material stream, and only a marginal $20 \mathrm{~kW}_{e l} / \mathrm{MW}_{\text {wood }}$ can be by-produced from the $52 \mathrm{~kW}$ th $/ \mathrm{MW}_{\text {wood }}$ that must be evacuated from the system.

\section{Exergy analysis}

\subsection{Method}

In order to further investigate the loss sources of the gasification systems, exergy balances considering the exergy value of material, thermal and mechanical streams (designated $\dot{E}_{y}, \dot{E}_{q}$ and $\dot{E}$ respectively) are defined for all process sections. The exergy losses $\dot{L}$ (Eq. 8) and efficiency $\eta$ (Eq. 9) are then calculated 

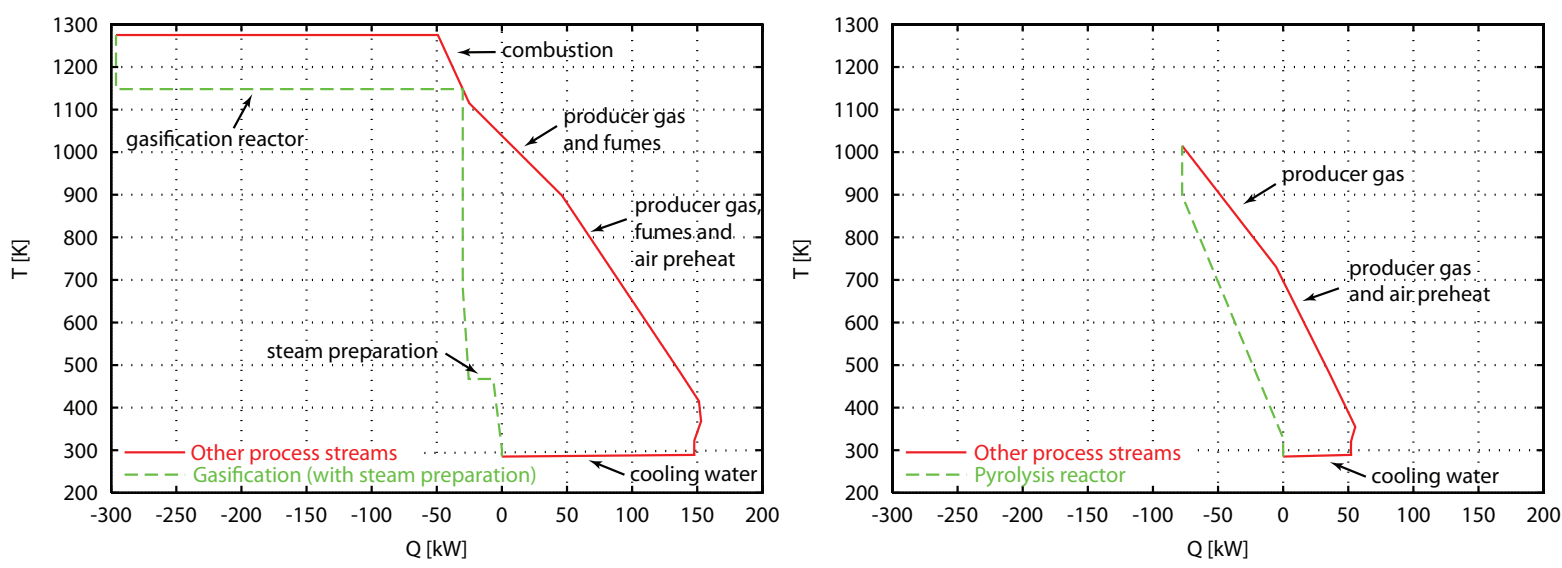

a - Heat supply for gasification and pyrolysis from utility and process streams (without the steam cycle).
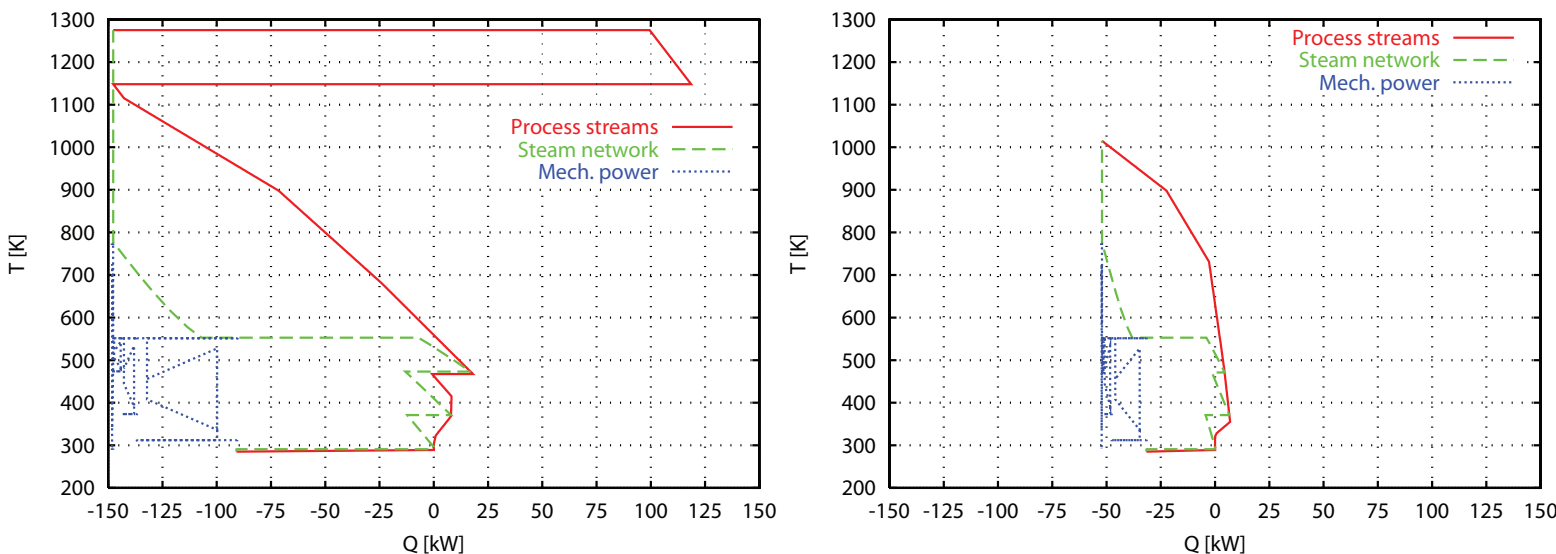

b - Heat recovery from the process streams with a steam cycle.
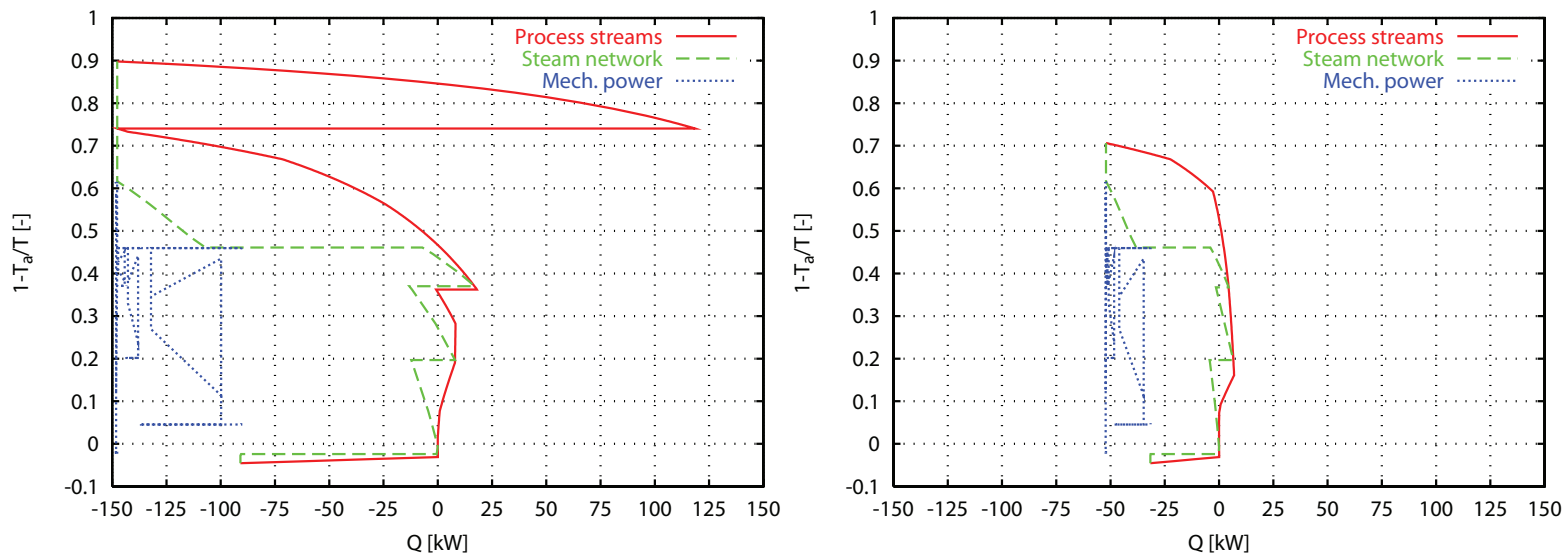

c - Exergy representation of the heat recovery from the process streams with a steam cycle.

Figure 2: Composite curves for FICFB (left) and Viking gasification (right). 


\begin{tabular}{llrr}
\hline Type & & FICFB & Viking \\
\hline Consumption & Wood & $1000 \mathrm{~kW}$ & $1000 \mathrm{~kW}$ \\
& Electricity & $2 \mathrm{~kW}$ & $2 \mathrm{~kW}$ \\
Production & Gas & $784 \mathrm{~kW}$ & $907 \mathrm{~kW}$ \\
& Electricity & $54 \mathrm{~kW}$ & $20 \mathrm{~kW}$ \\
\hline Losses & Gasification & $13 \mathrm{~kW}$ & $27 \mathrm{~kW}$ \\
& Combustion & $14 \mathrm{~kW}$ & - \\
& Gas cooling & $59 \mathrm{~kW}$ & $22 \mathrm{~kW}$ \\
& Cooling water & $91 \mathrm{~kW}$ & $32 \mathrm{~kW}$ \\
& Total & $177 \mathrm{~kW}$ & $81 \mathrm{~kW}$ \\
\hline Efficiencies & $\varepsilon_{c g}$ & $78.4 \%$ & $90.7 \%$ \\
& $\varepsilon_{\text {tot }}$ & $83.8 \%$ & $92.5 \%$ \\
\hline
\end{tabular}

Table 6: Energy balances. Note that the total consumption must not necessarily equal the total production and losses since the consumption and production terms are based on lower heating value, but the gas cooling loss includes condensation.

according to:

$$
\begin{aligned}
\dot{L}= & \sum \dot{E}_{y}^{+}+\sum \dot{E}_{q}^{+}+\sum \dot{E}^{+} \\
& -\left(\sum \dot{E}_{y}^{-}+\sum \dot{E}_{q}^{-}+\sum \dot{E}^{-}\right) \\
\eta=1 & -\frac{\dot{L}}{\sum \dot{E}_{y}^{+}+\sum \dot{E}_{q}^{+}+\sum \dot{E}^{+}}
\end{aligned}
$$

where superscripts ' + ' and '-' refer to streams entering and leaving the section, respectively. The exergy value of material streams is determined by adding its exergy value at atmospheric temperature $T_{a}$ and the exergy necessary for heating the stream:

$$
\begin{aligned}
\dot{E}_{y} & =\dot{m}\left[\Delta k^{0}+\int_{T_{a}}^{T} c_{p}\left(1-\frac{T_{a}}{T}\right) d T\right] \\
& =\dot{m}\left[\Delta k^{0}+c_{p}\left(T-T_{a}\left(1+\ln \left(T / T_{a}\right)\right)\right]\right.
\end{aligned}
$$

where $\Delta k^{0}$ is the exergy value per unit mass and $c_{p}$ the specific sensible heat at constant pressure. In this formulation, the contribution of the pressure is not included in $\dot{E}_{y}$, since the whole system operates at atmospheric pressure. The assumption of a constant $c_{p}$ is also used to determine the exergy value of the thermal streams:

$$
\begin{aligned}
\dot{E}_{q} & =\int_{T_{1}}^{T_{2}}\left(1-\frac{T_{a}}{T}\right) d \dot{Q} \\
& =\dot{m} \int_{T_{1}}^{T_{2}} c_{p}\left(1-\frac{T_{a}}{T}\right) d T \\
& =\dot{m} c_{p}\left[\left(T_{2}-T_{1}\right)-T_{a} \cdot \ln \left(T_{2} / T_{1}\right)\right] \\
& =\dot{Q}\left(1-T_{a} \cdot \frac{\ln \left(T_{2} / T_{1}\right)}{\left(T_{2}-T_{1}\right)}\right)
\end{aligned}
$$

Finally, the exergy value of mechanical streams equals is energy value $\dot{E}$.

\subsection{Results and discussion}

Complementary to the energy conversion analysis of the previous section, the exergy inventory of Table 7 highlights that the principal irreversible losses occur in the reactive part of the processes. A comparison of the gasifiers thereby shows that the exergy depletion in directly heated gasification is higher than in the indirectly heated reactor since partial oxidation occurs. However, this loss exactly equals out with 


\begin{tabular}{|c|c|c|c|c|}
\hline \multirow[b]{3}{*}{ Section } & \multicolumn{2}{|c|}{ FICFB } & \multicolumn{2}{|c|}{ Viking } \\
\hline & $\dot{L}$ & $\eta$ & $\dot{L}$ & $\eta$ \\
\hline & {$[\mathrm{kW}]$} & {$[\%]$} & {$[\mathrm{kW}]$} & {$[\%]$} \\
\hline Gasification $^{\mathrm{a}}$ & 176 & 87.4 & 245 & 80.2 \\
\hline Combustion & 71 & 80.5 & - & - \\
\hline \multicolumn{5}{|l|}{ Heat transfer } \\
\hline - above pinch & 32 & 85.8 & - & - \\
\hline - below pinch & 27 & 83.1 & 16 & 83.3 \\
\hline Gas cooling $^{\mathrm{b}}$ & 24 & 75.4 & 13 & 87.1 \\
\hline Steam turbine & 12 & 86.7 & 4 & 86.0 \\
\hline Total & 342 & 70.8 & 278 & 76.6 \\
\hline a including py & & & & \\
\hline
\end{tabular}

Table 7: Exergy losses and efficiencies.

the combined depletion in gasification and combustion of the FICFB technology. As already perceived in the energy integration analysis, it is the consequences of the combustion that induce the difference in performance. Exergy analysis thereby allows one to directly quantify the potential loss due to the degradation of valuable thermal energy in heat transfer. Since the loss in mechanical energy potential corresponds to the surface area between the uncorrected hot and cold streams in the exergy composite curves, it is clear that it is impossible to entirely recover the potential of the elevated amount of sensible heat of hot fumes and wet producer gas. As illustrated in Figure 2c, the indirect heat transfer from combustion to gasification above the pinch increases the exergy loss of this section by 13\%. Together with the depletion due to the heat transfer below the pinch and the gas cooling section, this results in an overall exergy efficiency of $70.8 \%$ for FICFB gasification, while $76.6 \%$ is reached by Viking technology.

\section{Potential process improvements}

The energy integration and exergy analysis identifies that the main drawback of the FICFB gasification process is its elevated heat requirement at high temperature. This results in a relatively low cold gas efficiency, and the irreversible losses in all process sections do not allow for entirely recovering the considerable amount of sensible heat from the fumes and the wet producer gas as electricity. By mainly targeting to decrease the minimum energy requirement (MER) above the pinch and the exergy losses in the reactive steps, this section presents measures to increase the cold gas and total process efficiency.

\subsection{Fuel choice}

In the FICFB demonstration plant, the combustion zone is fed with additional cold, clean producer gas to balance the heat demand of the gasification (Hofbauer et al., 2002). This has the main advantage that the gas handling is conveniently simple, but it consumes energy from above the pinch to heat the cold gas in the combustion zone. In order to satisfy the heat demand of the gasification reactor in a more efficient way, hot producer gas could be withdrawn from the gasifier outlet. Although the actual MER of $266 \mathrm{~kW}_{\text {th }} / \mathrm{MW}_{\text {wood }}$ does not change, no more heat from combustion is used to preheat the fuel. As shown in Table 8, the exergy losses in the combustion and the energy losses in the cooling water are reduced, and less energy must be withdrawn from the product stream. An advantageous side-effect is further observed in the gas cooling section since less gas is processed. Overall, using the hot and dirty producer gas instead of clean and dry one would allow for increasing the cold gas and total efficiencies by $3 \%$ and $2 \%$, respectively. 


\begin{tabular}{|c|c|c|c|c|c|c|c|c|}
\hline \multirow[b]{4}{*}{ Type } & \multirow{4}{*}{$\begin{array}{r}\text { Pretreatment } \\
\text { Fuel } \\
\text { Humidity }\end{array}$} & \multicolumn{6}{|c|}{ FICFB } & \multirow{3}{*}{$\begin{array}{r}\text { Viking } \\
\text { Pyrolysis } \\
\text { none }\end{array}$} \\
\hline & & none & none & Drying & Drying & Drying & Pyrolysis & \\
\hline & & cold gas & hot gas & cold gas & hot gas & dry wood & cold gas & \\
\hline & & $30 \%$ & $30 \%$ & $15 \%$ & $15 \%$ & $15 \%$ & $30 \%$ & $30 \%$ \\
\hline \multirow[t]{2}{*}{ Consumption } & Wood & $1000 \mathrm{~kW}$ & $1000 \mathrm{~kW}$ & $1000 \mathrm{~kW}$ & $1000 \mathrm{~kW}$ & $1000 \mathrm{~kW}$ & $1000 \mathrm{~kW}$ & $1000 \mathrm{k} W$ \\
\hline & Electricity & $2 \mathrm{~kW}$ & $2 \mathrm{~kW}$ & $4 \mathrm{~kW}$ & $4 \mathrm{~kW}$ & $4 \mathrm{~kW}$ & $2 \mathrm{~kW}$ & $2 \mathrm{~kW}$ \\
\hline \multirow[t]{2}{*}{ Production } & Gas & $784 \mathrm{~kW}$ & $814 \mathrm{~kW}$ & $847 \mathrm{~kW}$ & $869 \mathrm{~kW}$ & $874 \mathrm{~kW}$ & $888 \mathrm{~kW}$ & $907 \mathrm{~kW}$ \\
\hline & Electricity & $56 \mathrm{~kW}$ & $47 \mathrm{~kW}$ & $30 \mathrm{~kW}$ & $23 \mathrm{~kW}$ & $23 \mathrm{~kW}$ & $22 \mathrm{~kW}$ & $20 \mathrm{~kW}$ \\
\hline Energy & Drying & - & - & $19 \mathrm{~kW}$ & $19 \mathrm{~kW}$ & $19 \mathrm{~kW}$ & - & $\overline{-}-$ \\
\hline \multirow[t]{5}{*}{ losses } & Gasification & $13 \mathrm{~kW}$ & $13 \mathrm{~kW}$ & $10 \mathrm{~kW}$ & $10 \mathrm{~kW}$ & $9 \mathrm{~kW}$ & $9 \mathrm{~kW}$ & $27 \mathrm{~kW}$ \\
\hline & Combustion & $14 \mathrm{~kW}$ & $14 \mathrm{~kW}$ & $12 \mathrm{~kW}$ & $11 \mathrm{~kW}$ & $10 \mathrm{~kW}$ & $10 \mathrm{~kW}$ & - \\
\hline & Gas cooling & $59 \mathrm{~kW}$ & $47 \mathrm{~kW}$ & $59 \mathrm{~kW}$ & $50 \mathrm{~kW}$ & $50 \mathrm{~kW}$ & $59 \mathrm{~kW}$ & $22 \mathrm{~kW}$ \\
\hline & Cooling water & $91 \mathrm{~kW}$ & $75 \mathrm{~kW}$ & $48 \mathrm{~kW}$ & $36 \mathrm{~kW}$ & $39 \mathrm{~kW}$ & $28 \mathrm{~kW}$ & $32 \mathrm{~kW}$ \\
\hline & Total & $177 \mathrm{~kW}$ & $149 \mathrm{~kW}$ & $148 \mathrm{~kW}$ & $126 \mathrm{~kW}$ & $127 \mathrm{~kW}$ & $106 \mathrm{~kW}$ & $81 \mathrm{~kW}$ \\
\hline Exergy & Drying & - & - & $12 \mathrm{~kW}$ & $12 \mathrm{~kW}$ & $12 \mathrm{~kW}$ & - & $\overline{-}-$ \\
\hline \multirow[t]{8}{*}{ losses } & Gasification & $176 \mathrm{~kW}$ & $176 \mathrm{~kW}$ & $154 \mathrm{~kW}$ & $154 \mathrm{~kW}$ & $132 \mathrm{~kW}$ & $150 \mathrm{~kW}$ & $245 \mathrm{~kW}$ \\
\hline & Combustion & $71 \mathrm{~kW}$ & $61 \mathrm{~kW}$ & $57 \mathrm{~kW}$ & $50 \mathrm{~kW}$ & $71 \mathrm{~kW}$ & $49 \mathrm{~kW}$ & - \\
\hline & Heat transfer & & & & & & & \\
\hline & - above pinch & $32 \mathrm{~kW}$ & $33 \mathrm{~kW}$ & $26 \mathrm{~kW}$ & $27 \mathrm{~kW}$ & $22 \mathrm{~kW}$ & $23 \mathrm{~kW}$ & - \\
\hline & - below pinch & $27 \mathrm{~kW}$ & $24 \mathrm{~kW}$ & $34 \mathrm{~kW}$ & $32 \mathrm{~kW}$ & $30 \mathrm{~kW}$ & $25 \mathrm{~kW}$ & $16 \mathrm{~kW}$ \\
\hline & Gas cooling & $24 \mathrm{~kW}$ & $19 \mathrm{~kW}$ & $24 \mathrm{~kW}$ & $20 \mathrm{~kW}$ & $20 \mathrm{~kW}$ & $24 \mathrm{~kW}$ & $13 \mathrm{~kW}$ \\
\hline & Steam turbine & $12 \mathrm{~kW}$ & $9 \mathrm{~kW}$ & $2 \mathrm{~kW}$ & $0 \mathrm{~kW}$ & $1 \mathrm{~kW}$ & $3 \mathrm{~kW}$ & $4 \mathrm{~kW}$ \\
\hline & Total & $342 \mathrm{~kW}$ & $322 \mathrm{~kW}$ & $309 \mathrm{~kW}$ & $295 \mathrm{~kW}$ & $288 \mathrm{~kW}$ & $274 \mathrm{~kW}$ & $278 \mathrm{~kW}$ \\
\hline \multirow[t]{10}{*}{ Efficiencies } & $\varepsilon_{c g}$ & $78.4 \%$ & $81.4 \%$ & $84.7 \%$ & $86.9 \%$ & $87.4 \%$ & $88.8 \%$ & $90.7 \%$ \\
\hline & $\varepsilon_{t o t}$ & $83.8 \%$ & $85.9 \%$ & $87.2 \%$ & $88.7 \%$ & $89.4 \%$ & $91.0 \%$ & $92.5 \%$ \\
\hline & $\eta_{\text {gasification }}$ & $87.4 \%$ & $87.4 \%$ & $88.8 \%$ & $88.8 \%$ & $88.7 \%$ & $89.0 \%$ & $80.2 \%$ \\
\hline & $\eta_{\text {combustion }}$ & $80.5 \%$ & $82.8 \%$ & $80.6 \%$ & $82.6 \%$ & $74.2 \%$ & $80.7 \%$ & - \\
\hline & $\eta_{H T, \text { abovepinch }}$ & $85.8 \%$ & $85.7 \%$ & $85.8 \%$ & $85.6 \%$ & $85.9 \%$ & $85.7 \%$ & - \\
\hline & $\eta_{H T, \text { belowpinch }}$ & $83.1 \%$ & $83.0 \%$ & $80.4 \%$ & $79.9 \%$ & $80.0 \%$ & $82.6 \%$ & $83.3 \%$ \\
\hline & $\eta_{\text {gas cooling }}$ & $75.4 \%$ & $75.4 \%$ & $75.4 \%$ & $75.4 \%$ & $75.4 \%$ & $75.4 \%$ & $87.1 \%$ \\
\hline & $\eta_{\text {steam turbine }}$ & $86.7 \%$ & $87.3 \%$ & $97.1 \%$ & $99.3 \%$ & $98.3 \%$ & $93.7 \%$ & $86.0 \%$ \\
\hline & $\eta_{c g}$ & $66.2 \%$ & $68.7 \%$ & $71.5 \%$ & $73.4 \%$ & $73.9 \%$ & $75.0 \%$ & $75.0 \%$ \\
\hline & $\eta_{t o t}$ & $70.8 \%$ & $72.6 \%$ & $73.7 \%$ & $75.0 \%$ & $75.5 \%$ & $76.9 \%$ & $76.6 \%$ \\
\hline
\end{tabular}

Table 8: Energy and exergy balances for system modification of the FICFB gasification. For comparison, the original performance is reprinted in the first and last rows.

\subsection{Pretreatment}

In addition to changing the fuel to satisfy the energy requirement in a more efficient way, the goal of pretreating the feed is to inherently reduce the exergy losses and the heat demand of gasification. However, this requires to use additional equipment or to change the design of the gasifier. In addition to constructional modifications, a preprocessed feed is expected to decrease the $\Delta T$ value and thus reach closer to equilibrium conditions, or it would allow for reducing the vessel size.

\subsubsection{Drying}

A simple way to limit the losses in the gasifier is to remove the humidity of the feed by drying. This reduces the heat consumption above the pinch for evaporating water, which is easily satisfied with sensible heat at low temperature. A technology model for convective drying with flue gas or air has been developed and reported in previous work (Gassner and Maréchal, 2009b). Based on sorption isotherms, the model takes the temperature of the drying medium and the humidity of the solid into account. Since provided elsewhere, a detailed description is not repeated here, and only the modelled performance in 


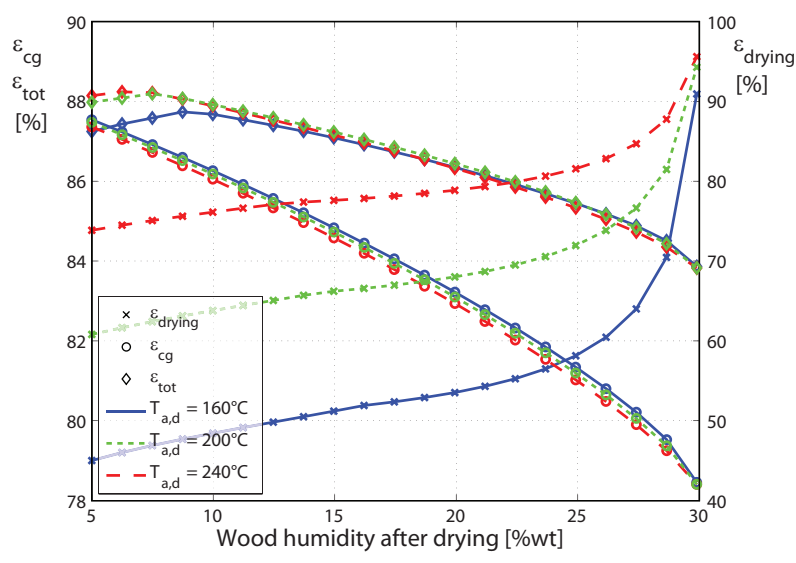

Figure 3: Drying efficiency and impact of drying on the process performance.

terms of drying efficiency $\varepsilon_{\text {drying }}$ is reported:

$$
\varepsilon_{\text {drying }}=\frac{\Delta h_{\text {vap }} \dot{m}_{H 2 O, \text { vap }}+\dot{Q}_{\text {drywood }}}{\dot{Q}_{\text {air preheat }}+\dot{E}_{\text {fan }}}
$$

where $\Delta h_{\text {vap }}$ represents the vaporisation enthalpy of water, $\dot{m}_{H 2 O, v a p}$ the amount of evaporated water in the dryer, $\dot{Q}_{d r y w o o d}$ and $\dot{Q}_{\text {air preheat }}$ the sensible heat of the dried wood and preheated air, and $\dot{E}_{f a n}$ the electric power consumption of the fan. Figure 3 shows the drying efficiency for three different air preheat temperature levels and the impact of drying on the cold gas and total efficiency of the process. Due to the large amount of heat that is available in this temperature range, the process efficiencies are not sensible to the drying efficiency. Only for very intense drying at low efficiency, the usage of heat gets conflictive with the electricity generation in the Rankine cycle. More importantly, the graph shows that the process performance is considerably increased by drying the feed. At a humidity level of $15 \%$ detailed in the comparative table (Tab. 8), the cold gas efficiency is increased by more than $6 \%$ compared to wood at $30 \%$ humidity. Since heat below the pinch is used, the MER is decreased by $18 \%$ from 266 to 217 $\mathrm{kW}_{t h} / \mathrm{MW}_{\text {wood }}$ and the exergy losses due to water evaporation at high temperature in the gasifier drop by more than $12 \%$. Drying therefore appears as a chemical heat pump.

In analogy with using hot instead of cold producer gas, some more benefit from drying can be obtained if the heat demand is satisfied with dried wood. Since less feed material is processed, the MER is further reduced to $185 \mathrm{~kW}_{t h} / \mathrm{MW}_{\text {wood }}$, and the cold gas efficiency increases by $9 \%$ overall compared to the reference technology. However, this solution would require a technical redesign of the combustion chamber and adding a biomass hopper.

\subsubsection{Pyrolysis}

Alternatively to installing a wood dryer, it is conceivable to feed the FICFB gasification reactor via the same type of screw pyrolysis device used in Viking gasification. This would have an amplified beneficial effect on the conversion efficiency, since the humidity is completely evaporated and the endothermal decomposition is set on with heat below the pinch. By reducing the MER to $185 \mathrm{~kW}_{t h} / \mathrm{MW}_{\text {wood }}$, the comparative table (Tab. 8) shows that more than $10 \%$ improvement in cold gas and $7 \%$ in total efficiency compared to the reference solution is possible. If hot producer gas is furthermore used to supply the remaining heat, the cold gas and total efficiency increase to $90.5 \%$ and $92.2 \%$ in terms of energy and $76.4 \%$ and $77.9 \%$ in terms of exergy, respectivly. With similar pretreatment, the performance of FICFB gasification is thus very close to Viking gasification, and might even exceed it with respect to the indicators based on exergy.

The conceptual flowsheet with a practicable structure of the heat exchanger network and the corresponding composite curve of this process option are shown in Figure 4. According to the calculations, 

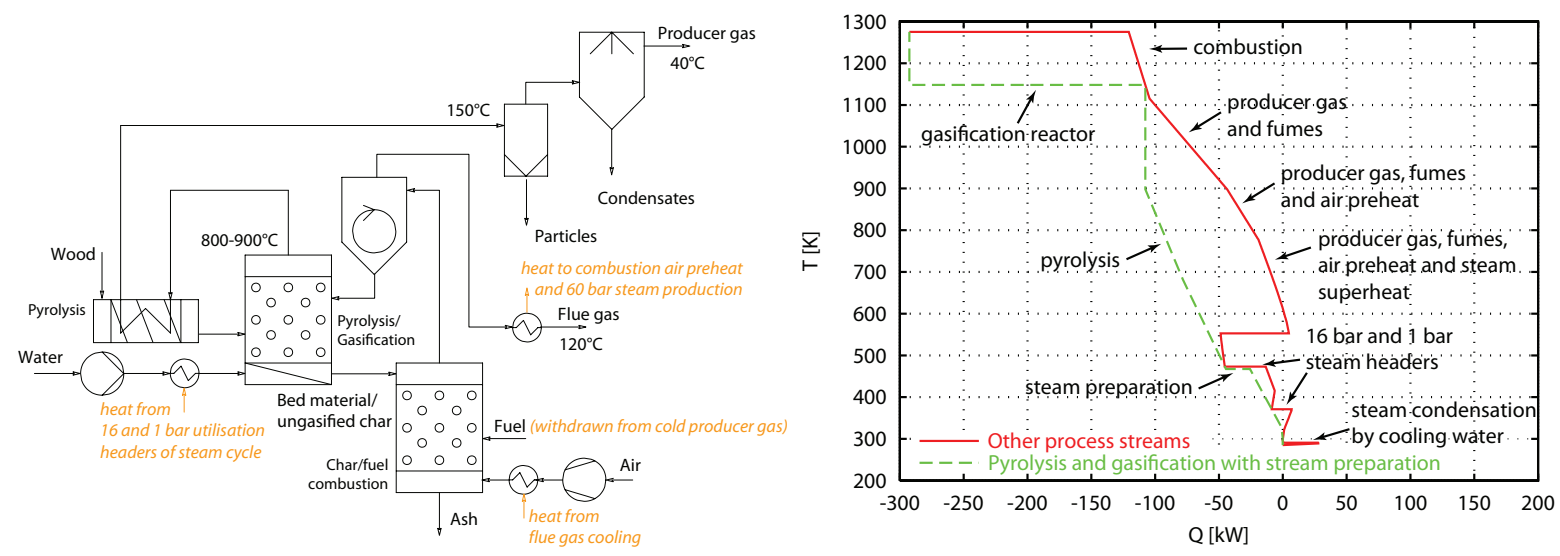

Figure 4: Modified flowsheet with outline of heat exchanger network (left) and composite curve of FICFB gasification with feed pretreatment by Viking pyrolysis.

the sensible heat of the producer gas balances the heat demand of the pyrolysis. It could thus be cooled in the jacket of the pyrolysis screw before entering the cold gas cleaning. The sensible heat of the fumes is left to preheat the combustion air and to produce steam in order to cogenerate electricity via the steam Rankine cycle.

\section{Performance in SNG production}

Producer gas from gasification is generally not a product on its own, but further converted to electricity, chemicals or fuels. Obviously, the overall performance of such systems does not only rely on the gasifier efficiency, but also on its integration with the rest of the system. For the two gasification systems, this effect is studied at the example of SNG production, which is a promising alternative to liquid synthesis fuels for transport applications. In such a process, clean producer gas is catalytically converted to methane by reforming the higher hydrocarbons (Eq. 13) and methanation of $\mathrm{CO}$ and $\mathrm{H}_{2}$ (Eq. 14) to thermodynamic equilibrium at $300-400^{\circ} \mathrm{C}$, whereas the necessary $\mathrm{CO}$ is provided by the simultaneously occurring water gas shift reaction (Eq. 4):

$$
\begin{array}{ll}
\mathrm{C}_{2} \mathrm{H}_{4}+2 \mathrm{H}_{2} \mathrm{O} \rightleftharpoons 2 \mathrm{CO}+4 \mathrm{H}_{2} & \Delta \tilde{h}_{r}^{0}=209 \mathrm{~kJ} / \mathrm{mol} \\
\mathrm{CO}+3 \mathrm{H}_{2} \rightleftharpoons \mathrm{CH}_{4}+\mathrm{H}_{2} \mathrm{O} & \Delta \tilde{h}_{r}^{0}=-206 \mathrm{~kJ} / \mathrm{mol}
\end{array}
$$

As producer gas from biomass feedstock generally lacks hydrogen to be completely reformed into methane, a considerable amount of $\mathrm{CO}_{2}$ is by-produced in these reactions. In order to inject the gas into grid, the crude product must be upgraded to natural gas quality by drying and removal of the bulk $\mathrm{CO}_{2}$ to reach a Wobbe Index of at least $13.3 \mathrm{kWh}_{H H V} / \mathrm{Nm}^{3}$. With both producer gas compositions of Table 4 , this criterion can however not be met without removing the nitrogen. Instead of a cumbersome posttreatment, nitrogen is more conveniently avoided by primary measures directly in gasification. In FICFB gasification, the relatively small amount of nitrogen the producer gas is due to its usage for feed inertisation and some slip from the gasification chamber. In a new plant, inertisation could be done with $\mathrm{CO}_{2}$, and by taking special care to nitrogen slip in the design, it is assumed that its concentration is decreased to $0.5 \%$ vol. In Viking gasification, the nitrogen is introduced with the air for partial oxidation and can only be avoided by using oxygen. In this work, either ion transfer membranes (ITM) or electrolysis are considered for oxygen production. ITM is an emerging technology that is not yet commercially proven. It is expected to consume about $147 \mathrm{kWh}_{e l} / \operatorname{ton}_{O 2}$ and $1.25 \mathrm{MWh}_{t h} / \operatorname{ton}_{O 2}$ to heat the air from $500^{\circ} \mathrm{C}$ up to the membrane's operating temperature of $900^{\circ} \mathrm{C}$ (van Stein et al., 2002). As an alternative, oxygen production by electrolysis is accompanied by an important by-production of hydrogen, which could itself be used in the methanation to increase the SNG yield from biomass (Gassner and Maréchal, 2008). 


\begin{tabular}{|c|c|c|c|c|c|c|c|c|c|}
\hline & \multirow[b]{2}{*}{ Unit } & \multicolumn{2}{|c|}{ gasification } & \multicolumn{3}{|c|}{ methanation } & \multicolumn{3}{|c|}{ CO2-removal } \\
\hline & & FICFB & Viking & FICFB & Viking & Viking $^{\mathrm{a}}$ & FICFB & Viking & Viking $^{\mathrm{a}}$ \\
\hline$\overline{\mathrm{C}_{2} \mathrm{H}_{4}}$ & $\%$ vol & 2.4 & - & - & - & - & - & - & - \\
\hline $\mathrm{CH}_{4}$ & $\%$ vol & 11.7 & 2.7 & 49.8 & 38.5 & 49.8 & 92.0 & 91.9 & 92.3 \\
\hline $\mathrm{H}_{2}$ & $\%$ vol & 41.9 & 46.5 & 3.0 & 2.3 & 3.0 & 4.8 & 5.0 & 4.8 \\
\hline $\mathrm{CO}$ & $\%$ vol & 22.8 & 28.4 & 0.1 & 0.1 & 0.1 & 0.1 & 0.2 & 0.1 \\
\hline $\mathrm{CO}_{2}$ & $\%$ vol & 20.6 & 22.0 & 46.1 & 58.3 & 46.5 & 1.0 & 1.1 & 1.3 \\
\hline $\mathrm{N}_{2}$ & $\%$ vol & 0.5 & 0.4 & 1.1 & 0.8 & 0.8 & 2.1 & 1.9 & 1.4 \\
\hline
\end{tabular}

a with hydrogen injection from electrolysis.

Table 9: Dry gas compositions, flowrates and energy balance in SNG production.

\begin{tabular}{|c|c|c|c|c|c|c|}
\hline \multirow[b]{3}{*}{ Type } & \multirow{3}{*}{$\begin{array}{l}\text { Pretreatment } \\
\mathrm{O}_{2} \text {-production }\end{array}$} & \multicolumn{3}{|c|}{ FICFB } & \multicolumn{2}{|c|}{ Viking } \\
\hline & & none & Drying & Pyrolysis & Pyrolysis & Pyrolysis \\
\hline & & none & none & none & ITM & Electrolysis \\
\hline \multirow[t]{6}{*}{ Chemical energy } & wood, wet, in & $1000 \mathrm{~kW}$ & $1000 \mathrm{~kW}$ & $1000 \mathrm{~kW}$ & $1000 \mathrm{~kW}$ & $1000 \mathrm{~kW}$ \\
\hline & $\begin{array}{l}\text { wood, dry } \\
\text { producer gas }\end{array}$ & $1000 \mathrm{~kW}$ & $1034 \mathrm{~kW}$ & $1000 \mathrm{~kW}$ & $1000 \mathrm{~kW}$ & $1000 \mathrm{~kW}$ \\
\hline & - gross & $1026 \mathrm{~kW}$ & $1026 \mathrm{~kW}$ & $1026 \mathrm{~kW}$ & $931 \mathrm{~kW}$ & $931 \mathrm{~kW}$ \\
\hline & - net & $770 \mathrm{~kW}$ & $839 \mathrm{~kW}$ & $875 \mathrm{~kW}$ & $896 \mathrm{~kW}$ & $931 \mathrm{~kW}$ \\
\hline & crude SNG, methanation & $672 \mathrm{~kW}$ & $730 \mathrm{~kW}$ & $762 \mathrm{~kW}$ & $724 \mathrm{~kW}$ & $973 \mathrm{~kW}$ \\
\hline & SNG, out & $645 \mathrm{~kW}$ & $704 \mathrm{~kW}$ & $734 \mathrm{~kW}$ & $698 \mathrm{~kW}$ & $941 \mathrm{~kW}$ \\
\hline \multirow[t]{3}{*}{ electric energy } & consumption & $33 \mathrm{~kW}$ & $39 \mathrm{~kW}$ & $37 \mathrm{~kW}$ & $57 \mathrm{~kW}$ & $433 \mathrm{~kW}$ \\
\hline & production & $109 \mathrm{~kW}$ & $82 \mathrm{~kW}$ & $82 \mathrm{~kW}$ & $94 \mathrm{~kW}$ & $117 \mathrm{~kW}$ \\
\hline & net production & $76 \mathrm{~kW}$ & $43 \mathrm{~kW}$ & $45 \mathrm{~kW}$ & $37 \mathrm{~kW}$ & $-316 \mathrm{~kW}$ \\
\hline \multirow[t]{4}{*}{ Efficiencies } & $\varepsilon_{c g}$ & $64.5 \%$ & $70.4 \%$ & $73.4 \%$ & $69.8 \%$ & $94.1 \%$ \\
\hline & $\varepsilon_{t o t}$ & $72.1 \%$ & $74.7 \%$ & $77.9 \%$ & $73.6 \%$ & $71.5 \%$ \\
\hline & $\eta_{c g}$ & $56.2 \%$ & $61.2 \%$ & $63.9 \%$ & $60.8 \%$ & $81.9 \%$ \\
\hline & $\eta_{t o t}$ & $62.5 \%$ & $64.9 \%$ & $67.6 \%$ & $63.9 \%$ & $64.7 \%$ \\
\hline
\end{tabular}

Table 10: Chemical energy flows and overall energy balances in SNG production.

With the process model develop in previous work (Gassner and Maréchal, 2009b), the system performance for both gasifiers is determined by considering that the bulk $\mathrm{CO}_{2}$ is removed by pressure swing adsorption in order to meet the condition on the Wobbe Index. In order to limit the number of options to be discussed, it is assumed that the process heat demand is satisfied with cold producer gas. For Viking gasification, the steam network used for energy recovery is slightly adapted to the different process conditions. Instead of steam production at $60 \mathrm{bar}$, methanation at $320^{\circ} \mathrm{C}$ and a low amount of heat available above favours steam production at 50 bar and superheating to $480^{\circ} \mathrm{C}$ (ITM) or $460^{\circ} \mathrm{C}$ (electrolysis).

Tables 9 shows the computed gas compositions for this process setup. With the chosen approach for the gasification modelling, the ratios between the species are preserved. As the producer gas from indirectly heated, steam-blown gasification contains more (atomic) hydrogen, the relative share of methane in the crude product is higher than the one obtained from the partially oxidised producer gas. However, this share equals out if by-produced $\mathrm{H}_{2}$ from water separation is added before methanation. In order to compare the performance of both in the system, the chemical energy flows and overall efficiencies are shown in Table 10 for the pretreatment options discussed in Section 5. According to the thermodynamic analysis of the gasifiers, the net producer gas yield from gasification is in all cases higher for Viking technology. After methanation, however, this advantage is considerably reduced or even lost if the feed is dried or pyrolysed. As less methane is present in the partially oxidised producer gas, the equilibrium conversion to methane is higher, and more energy is released in the exothermal methanation reactions. The system with FICFB gasification actually benefits from the fact that the producer gas is further away from equilibrium because the gasification reactions are less endothermal - and the ones in methanation less exothermal. With respect to chemical and overall performance, Viking gasification with pure oxygen is therefore only better if the FICFB feed is not dried. As for the isolated performance, drying and 
pyrolysis considerably increase the cold gas efficiency of the latter by $6 \%$ and $9 \%$. With an potential overall efficiency of almost $78 \%$ for FICFB gasification with pyrolysis pretreatment, this technology seems clearly advantageous for SNG production. Directly heated gasification with oxygen from electrolysis shows a very high SNG yield and an acceptable total efficiency especially in terms of exergy. The balance demonstrates that it is a way to increase the SNG yield from wood by converting electricity to SNG. From a practical point of view, the rationality of such a conversion might however be doubted since the energy and exergy value of the gas are technologically by far not recoverable to supply a useful energy service.

\section{Conclusions}

Using adjusted equilibrium equations in flowsheet calculations and performing the process integration with pinch analysis, indirectly heated, fluidised bed gasification with steam as gasifying agent (FICFB) and two-stage, fixed bed gasification with air as gasifying agent (Viking) are compared with respect to the thermodynamic conversion and energetic performance. The modelling approach allows for accurately reproducing experimentally observed gas compositions and to quantify the difference to thermodynamic equilibrium. Directly heated, fixed bed gasifier is observed to be closer to equilibrium than FICFB gasification. The reason for this is suspected in an unequal temperature distribution in the reactor and intermediate heating of the pyrolysis product for tar cracking.

In order to analyse the overall performance and identify the major losses, the energy integration has been completed with an exergy analysis of the different process sections. Due to a pinch of the FICFB process streams at high temperature, its hot utility requirements satisfied with cold producer gas are elevated and the exergy potential of the sensible heat is only partially recovered. Viking gasification proves particularly efficient since part of the sensible heat is used to dry and start the endothermal decomposition at low temperature. With the actual technology at demonstration status, the advantage of a nitrogen free product gas with high calorific value obtained from FICFB gasification is thus penalised by a $12 \%$ lower cold gas and $9 \%$ lower overall energy efficiency for wood at $30 \%$ humidity. However, process integration allows for partly compensating the exergy losses and substantial improvements can be obtained by satisfying the heat requirement of the plant with other streams and using additional technology. In particular, balancing the heat requirement with hot producer gas would increase the cold gas and total energy efficiencies by $3 \%$ and $2 \%$, drying the feed to $15 \%$ humidity allows for a $6 \%$ and $3 \%$ increase, and using the same type of screw pyrolysis than in Viking gasification improves these efficiencies by $10 \%$ and $7 \%$, respectively. By applying several of these modifications, the gap to Viking gasification is reduced in terms of energy efficiency, and even surmounted in terms of exergy efficiency.

A final comparison of the performance of both gasification technologies in an integrated plant for SNG production shows that the advantage in cold gas efficiency is quickly compensated by a higher heat release in methanation. The fact that the producer gas from FICFB gasification is further away from equilibrium turns out to be an advantage since the endothermicity of the gasification reactions is restrained and less chemical energy is lost in methanation.

\section{References}

Bacon, D., Downie, J., Hsu, J., Peters, J., 1982. Fundamentals of thermochemical biomass conversion. Elsevier, London, Ch. Modeling of fluidized bed wood gasifiers, pp. 717-732.

Belsim SA, last visited 04/2009. Vali IV. www.belsim.com.

Brown, D., 2007. Development and application of an equilibrium reaction modelling approach and of heat integration methodologies for the conceptual design of biomass gasification energy conversion systems. Ph.D. thesis, Tokyo Institute of Technology. 
Brown, D., Gassner, M., Fuchino, T., Maréchal, F., 2009. Thermo-economic analysis for the optimal conceptual design of biomass gasification energy conversion systems. Applied Thermal Engineering $29,2137-2152$.

Craig, K., Mann, M., 1996. Cost and performance analysis of biomass-based integrated gasification combined-cycle power systems. Tech. rep., NREL, Colorado, USA.

Duret, A., Friedli, C., Maréchal, F., 2005. Process design of Synthetic Natural Gas (SNG) production using wood gasification. Journal of Cleaner Production 13, 1434-1446.

Fassinou, W. F., Van de Steene, L., Toure, S., Volle, G., Girard, P., 2009. Pyrolysis of pinus-pinaster in a two-stage gasifier: Influence of processing parameters and thermal cracking of tar. Fuel Processing Technology 90, 75-90.

Fryda, L., Panopoulos, K. D., Karl, J., Kakaras, E., 2008. Exergetic analysis of solid oxide fuel cell and biomass gasification integration with heat pipes. Energy 33, 292-299.

Gassner, M., Maréchal, F., 2008. Thermo-economic optimisation of the integration of electrolysis in synthetical natural gas production from wood. Energy 33, 189-198.

Gassner, M., Maréchal, F., 2009a. Methodology for the optimal thermo-economic, multi-objective design of thermochemical fuel production from biomass. Computers and Chemical Engineering 33, 769-781.

Gassner, M., Maréchal, F., 2009b. Thermo-economic process model for thermochemical production of synthetic natural gas (SNG) from lignocellulosic biomass. Submitted in revised form to Biomass and Bioenergy, .

Gøbel, B., Henriksen, U., Ahrenfeldt, J., Jensen, T., Hindsgaul, C., Bentzen, J., Sørensen, L., 2004. Status -2000 hours of operation with the Viking gasifier. In: Proceedings of the 2nd World Conference and Technology Exhibition on Biomass for Energy and Industry. Rome.

Gumz, W., 1950. Gas producers and blast furnaces. Wiley, New York.

Hamelinck, C. N., Faaij, A. P. C., den Uil, H., Boerrigter, H., 2004. Production of FT transportation fuels from biomass; technical options, process analysis and optimisation, and development potential. Energy 29, 1743-1771.

Henriksen, U., Ahrenfeldt, J., Bentzen, J., 2005. Langtidsforsøg med totrinsforgasseren "Viking”. Tech. Rep. MEK-ET-2005-7, DTU, Lyngby, Denmark.

Henriksen, U., Ahrenfeldt, J., Jensen, T., Gøbel, B., Bentzen, J., Hindsgaul, C., Sørensen, L., 2006. The design, construction and operation of a $75 \mathrm{~kW}$ two-stage gasifier. Energy 31, 1542-1553.

Heyne, S., Thunman, H., Harvey, S., 2008. Integration aspects for synthetic natural gas production from biomass based on a novel indirect gasification concept. In: PRES 2008, 11th Conference on Process Integration, Modelling and Optimisation for Energy Saving and Pollution Reduction. Prague.

Hofbauer, H., Rauch, R., Löeffler, G., Kaiser, S., Fercher, E., Tremmel, H., 2002. Six years experience with the FICFB-gasification process. In: Proceedings of the 12th European Conference and Technology Exhibition on Biomass for Energy, Industry and Climate Protection. Amsterdam, Netherlands.

Huang, H., Ramaswamy, S., 2009. Modeling biomass gasification using thermodynamic equilibrium approach. Applied Biochemistry and Biotechnology, Article in Press 154, 14-25.

Jarungthammachote, S., Dutta, A., 2007. Thermodynamic equilibrium model and second law analysis of a downdraft waste gasifier. Energy 32, 1660-1669. 
Karellas, S., Karl, J., Kakaras, E., 2008. An innovative biomass gasification process and its coupling with microturbine and fuel cell systems. Energy 33, 284-291.

Kersten, S., 2002. Biomass gasification in circulating fluidized beds. Ph.D. thesis, Twente University, Enschede.

Li, X. T., Grace, J. R., Lim, C. J., Watkinson, A. P., Chen, H. P., Kim, J. R., 2004. Biomass gasification in a circulating fluidized bed. Biomass and Bioenergy 26, 171-193.

Luterbacher, J., Fröling, M., Vogel, F., Maréchal, F., Tester, J. W., 2009. Hydrothermal gasification of waste biomass: Process design and life cycle assessment. Environmental Science and Technology 43, $1578-1583$.

Mozaffarian, M., Zwart, R. W. R., 2003. Feasibility of biomass/waste-related SNG production technologies. Tech. rep., ECN, Petten.

Omosun, A. O., Bauen, A., Brandon, N. P., Adjiman, C. S., Hart, D., 2004. Modelling system efficiencies and costs of two biomass-fuelled sofe systems. Journal of Power Sources 131, 96-106.

Pellegrini, L. F., de Oliveira Jr., S., 2007. Exergy analysis of sugarcane bagasse gasification. Energy 32, 314-327.

Perry, S., Klemeš, J., Bulatov, I., 2008. Integrating waste and renewable energy to reduce the carbon footprint of locally integrated energy sectors. Energy 33, 1489-1497.

Prins, M. J., Ptasinski, K. J., Janssen, F. J. J. G., 2007. From coal to biomass gasification: Comparison of thermodynamic efficiency. Energy 32, 1248-1259.

Pröll, T., Hofbauer, H., 2008. H2 rich syngas by selective co2 removal from biomass gasification in a dual fluidized bed system - process modelling approach. Fuel Processing Technology 89, 1207-1217.

Ptasinski, K. J., 2008. Thermodynamic efficiency of biomass gasification and biofuels conversion. Biofuels, Bioproducts and Biorefining 2, 239-253.

Ptasinski, K. J., Prins, M. J., Pierik, A., 2007. Exergetic evaluation of biomass gasification. Energy 32, $568-574$.

Rauch, R., written around 2004. Stromerzeugung aus Biomasse durch Wasserdampfvergasung. Tech. rep., Institut für Verfahrens-, Brennstoff- und Umwelttechnik, TU Wien, www.ficfb.at, last visited 04/2009.

Schuster, G., Löffler, G., Weigl, K., Hofbauer, H., 2001. Biomass steam gasification - an extensive parametric modeling study. Bioresorce Technology 77, 71-79.

Spath, P., Dayton, D., 2003. Preliminary screening - technical and economic assessment of synthesis gas to fuels and chemicals with emphasis on the potential for biomass-derived syngas. Tech. rep., NREL, Colorado, USA.

Stucki, S., 2005. Projet bois-methane. Rapport sur la clôture de la phase 1 du projet: Preuve de la faisabilité technique à l'échelle du laboratoire. Tech. rep., PSI, Villigen, Switzerland.

Szargut, J., Styrylska, T., 1964. Angenäherte Bestimmung der Exergie von Brennstoffen. BrennstoffWärme-Kraft 16, 589-636.

van Stein, E. E., Juwono, E., Demetri, E. P., 2002. The impact of ITM oxygen on economics for coalbased IGCC. In: Proceedings of the 27th International Technical Conference on Coal Utilization \& Fuel Systems. Clearwater, Florida.

Yoshikawa, K., 2006. R\&d (research and development) on distributed power generation from solid fuels. Energy 31, 1656-1665. 